\title{
ONLINE TEACHING-LEARNING DURING LOCKDOWN PERIOD FOR COVID-19 PANDEMIC IN SRI KRISHNA ARTS AND SCIENCE COLLEGE
}

\author{
Dr. R. Moorthy \\ Librarian, Sri Krishna Arts and Science College, Coimbatore
}

Manuscript Info

Manuscript History

Received: 09 December 2020

Final Accepted: 22 January 2021

Published: 10 February 2021

Online Published: March 2021

DOI: http://dx.doi.org/10.35337/EIJLITR.2021.1303

(C) Dr. R. Moorthy The Author. This is an open access article under the terms of the Creative Commons Attribution License 4.0, which allows use, distribution and reproduction in any medium, provided the original work is properly cited.

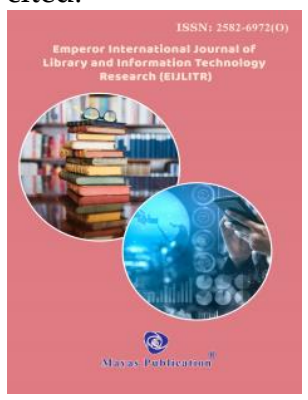

\section{Abstract}

The whole informative structure from fundamental for high level training has been collapsed during the lockdown season of COVID-19 Pandemic. This examination is the assessment of web training Learning modes got by the SKASC for the teaching learning measure. Advantages and Demerits of Online learning stage are furthermore analyzed.

Keywords: Online Teaching-Learning

\section{INTRODUCTION}

Covid, as an overall pandemic, has called for social isolating. Thusly to keep people associated with and freed from mental pressing factor, web learning can expect crucial part in pandemic period. Representatives can use virtual homerooms to instruct from home with exceedingly significant mechanical assemblies which makes online gatherings.

\section{Objectives}

$>$ To use distinctive online instruments and stages by SKASC during pandemic period.

$>$ Study the activities taken by Government of India to help electronic learning measure during the lockdown time span.

$>$ To component a couple of advantages and terrible signs of online learning.

\section{Valuable Online Learning Resources}

The going with resources are as cutting edge stages can be gotten to by the Faculty people, Research scientists and Students in high level training Institutions for advancement of their Knowledge. 
$>$ NDL (http://ndl.hitkgp.ac.in

$>$ Shodhganga (http://shodhganga:inflibnet.ac.in.)

$>$ CEC-UGC You tube channel (www.youtube.com/customer/cecedusat)

$>$ DELNET

$>$ INFLIBNET-N-List (nlist.inflibnet.ac.in)

$>$ E-PG Pathshala (epgp.inflibnet.ac.in)

$>$ Swayam Online Courses and other MOOCs (www.swayam.gov.in)

$>$ Vidwan (https://Vidwan: inflibnet in ac.in

$>$ EBSCO Database

$>$ Scopus, Web of Science, etc

Online Platforms that usage for live chronicles classes and the going with live video correspondence meeting stages are available in web.

$>$ Google Meet

$>$ Zoom

$>$ SKYPE

$>$ Facebook Live

$>$ YouTube Live

$>$ Uber Conference

$>$ Free Conference

$>$ Dingtale

$>$ Lark

$>$ Teams

$>$ True Conf. On the web

$>$ Slace Video calls

$>$ Lifesize GO

\section{Merits of Online Learning in Local Platforms}

$>$ Online Learning helps more beneficial usage of time which gatekeepers individuals from spread of COVID-19.

$>$ The understudies and researchers can get to the resources and go to the classes at their own place. It grants geographical reach even to commonplace or distant regions.

$>$ Online educating and learning system is a canny development.

$>$ The enlightening Institutions may consider using on the web evaluation programming which may help for coordinating on the web appraisals.

$>$ It can oblige more understudies at a particular time.

\section{Demerits}

$>$ It may incite aloofness for specific understudies being at their home and may nonappearance of poise.

$>$ Face to Face empowering climate is lost. Bury singular association among understudies and educators may hinder.

$>$ Online classes stacking to pressing factor, headache and eye issues, etc

\section{Teaching and Learning in SKASC}

\section{SKASC Online Classes}

Since the scene of COVID-19 began, some 1.37 billion understudies in 138 countries worldwide have been affected by school and school terminations. Since the whole country is under lockdown, e-guidance is the most astute decision left.

SKASC has started Online Classes for the UG and PG understudies since on 15 unique Departments of SKASC coordinated online classes satisfactorily. 
In the midst of COVID-19 Outbreak, SKASCians have not offered a relief for learning. Taking confidence in the manner that learning can happen wherever and under any circumstance, SKASC has progressed elearning through stages, for instance, myklassroom, Google Classroom and Youtube

\author{
The going with practices were driven during the COVID-19 Outbreak \\ $>$ Out of the case \\ $>$ Online Learning \\ $>$ Virtual Classrooms \\ $>$ Video Lectures \\ $>$ Project Reviews \\ $>$ Online Assignments \\ $>$ Presentations | Quiz \\ $>$ Group Activities \\ $>$ Online Exams \\ $>$ Digitalized Study \\ $>$ E-Resources \\ $>$ Online Assessments \\ $>$ Discussion Forums
}

The Covid pandemic deferred the tests yet couldn't stop it. After the GO from the public position to coordinate the End semester Exams, SKASC decided to lead tests basically through examily programming. The tests were coordinated with extreme control as indicated by the standards set some place close to the public position. There was one invigilator for each 15-20 understudies and they were noticed persistently. As understudies knew the meaning of their year's end tests, they collaborated to the most limit degree in the smooth direct of the overall huge number of tests. It was truly a troublesome endeavor for both the understudies and the invigilators; they took it up joyfully and winning in it.

\title{
Google Classroom
}

Google Classroom is a web organization made by Google for Educational Institutions that intend to smooth out making, scattering and surveying assignments in a paperless way. The fundamental job of Google Classroom is to streamline the route toward splitting reports between teachers and understudies. It merges Google Drive for task creation and movement, Google Docs, Sheets and Slides for making, Gmail for correspondence, and Google Calendar for booking. Sri Krishna College of Arts and Science is maybe the best customers of Google Classroom. The Students of our school are free to join Google class through a private code. Each class makes an alternate coordinator in the individual customer's Drive, where the understudy submits work to be assessed by an instructor. Compact applications, available for iOS and Android contraptions which let the understudies to take photos and join assignments, share archives from different applications, and access information detached. Teachers can evaluate the progression for each understudy, and in the wake of assessing, educators can return the understudy's work, close by comments.

\section{Myklassroom}

Sri Krishna Arts and Science College also uses another high level stage despite Google Classroom called as Myklassroom. It is an astounding blend of Social frameworks organization and E-learning. It gives an online communitarian stage to educating and learning. It energizes the front line study lobby, which would give coordinated induction to information, a get-together to inspect and adapt information, online talks, a staff to coordinate discussions, and throughout the day, consistently permission to homerooms wherever at whatever point. This is because we acknowledge that "A homeroom is essentially more than basically a record." And it has brought the certified investigation corridor experience on the web. With such inventive homeroom experience, the understudies come out easily. It is clear through the academic results of our understudies.

Myklassroom is a self-based teacher drove acknowledging which fuses media as text, picture, movement, online video and sound. They can in like manner interface with work force and individual class understudies, submit errands and go to on-line tests. The e-learning stage is met with long reach 
relational correspondence to enable the understudies to check out discusses smart teachers from various schools both in India and abroad. It furthermore engages understudies to learn past instructive arrangement and advanced learning in the subjects of their liking. M-learning is in like manner enabled for understudies through Google applications and Myklassroom.com.

Each understudy is outfitted with solitary email IDs and Login address through which understudy is selfintroduced to this overall association. Myklassroom.com is a self based educator drove learning. The understudies profile is dealt with outline of courses offered, separate staff-in-charge, particular insightful execution, semester support that are invigorated discontinuously. Beside responsibility myklassroom auto-content age module offers induction to rich substance and fabricates the transparency of the understudy. This noteworthy part is bored excellent unprecedented for Arts and Science in this piece of the country. E-Governance - Stay related from wherever, at whatever point: With the introduction of Google Apps for Education in the College, everything is thus saved in the cloud. Messages, chronicles, timetable and objections can be conferred, gotten to and adjusted on essentially any cell or tablet for local area work and study at whatever point, wherever.

Contribution from understudies on the ceaseless insightful activities is overcome the on-line e-learning stage myklassroom.com and through Google applications. Myklassroom.com is an extraordinary blend of long reach casual correspondence and e-learning stage, which changes the standard homeroom guidance to an online synergistic stage for instructing and learning. The foundation has introduced Real Time Experience Learning System (RTELS) in a joint exertion with myklassroom.com (electronic learning).

\section{CONCLUSION}

The e-learning stage has explored the learning connection through online stage for the understudies by partner them with comparative people around the globe. The stage in like manner gives content rich material and interfaces with the understudies to learn in an unpredictability free online media.

The myklassroom.com is used by the labor force for moving activity plan, address notes, PPTs and evaluation sheets for the understudies' utilization. M-learning is moreover available in the school through Google applications. The headway in the errand work is seen by the helpers through timesheet in myklassroom.com.

\section{REFERENCES}

1. Dr. Pravat Kumar Jena, "Online Learning during Lockdown Period for Covid 19 in India", International Journal of Multidisciplinary Education Research, Vol.9 No.5 (8), May 2020, ISSN :2277-7881, www.ijmer.in.82.

2. Lokanath Mishra, Tushar Gupta , Abha Shree , "Web training learning in high level training during lockdown season of COVID-19 pandemic", International Journal of Education Research Open, Vol.1, 2020,100012, Elsevier.

3. Google pursuit. Best Free Video Conferencing Tools. Recuperated on April 15, 2020

4. from https://www.owllabs.com/blog/video-conferencing-instruments

5. www.inflibnet.ac.in

6. www.nptel.ac.in

7. www.ugc.ac.in

8. www.myklassroom.com The e-learning stage has explored the learning connection through online stage for the understudies by partner them with comparative people around the globe. The stage in like manner gives content rich material and interfaces with the understudies to learn in an unpredictability free online media. The myklassroom.com is used by the labor force for moving activity plan, address notes, PPTs and evaluation sheets for the understudies' utilization. Mlearning is moreover available in the school through Google applications. The headway in the errand work is seen by the helpers through timesheet in myklassroom.com. 